\title{
IMPLEMENTASI PIECES FRAMEWORKUNTUK MENGANALISA KEBUTUHAN PENGGUNA PADA PERANCANGAN WEBSITE PT ALMICO RISET
}

\author{
Netci Hesvindrati \\ Magister Teknik Informatika, Sekolah Tinggi Manajemen Informatika dan \\ KomputerAMIKOMYogyakarta
}

\begin{abstract}
ABSTRAK
Penelitian ini bertujuan membuat analisa kebutuhan pengguna menggunakan framework PIECES (Performance, Information, Economics, Control, Efiiency, Services) untuk mengembangkan sebuah situs web dengan pendekatan RAD Extreme programming.Hasil akhir dari penelitian ini adalah dokumen kebutuhan pengguna (user requirement) yang nantinya akan menjadi dasar pengembangan situs web. Baik atau buruknya sebuah analisa kebutuhan pengguna dapat dinilai dari kesesuaian antara goal awal dengan pengujian sistem. Hasil penelitian menunjukkan bahwa secara fungsional situs yang dikembangkan sudah memenuhi kebutuhan pengguna.
\end{abstract}

Keyword: Extreme Programming, PIECES Framework, User Requirement

\begin{abstract}
This study aims to make an analysis of user needs using the framework PIECES (Performance, Information, Economics, Control, Efiiency, Services) to develop a website with Extreme RAD approach to programming. The end result of this research is the document needs of users (user requirement) which will be the basis for development of web sites. Good or bad a user needs analysis can be judged from the correspondence between the initial goal with the testing system. The results showed that the functional site developed already meet the needs of users.
\end{abstract}

Keywords: Extreme Programming, PIECES Framework, User Requirements 


\section{PENDAHULUAN}

Sebagai konsultan riset, bisnis jasa mengolah data dan penerjemahan, PT. Almico Riset melakukan proses bisnisnya secara sederhana dengan terlebih dahulu menangani pelanggannya yang berkonsultasi sesuai dengan jasa yang dibutuhkan dan yang dapat disediakan oleh PT Almico Riset. Setelah berkonsultasi, pelanggan kemudian memberikan order bersamaan dengan pembayaran DP. Order tersebut kemudian dikerjakan sesuai dengan kesepakatan project.

Sistem bisnis yang dilakukan oleh Almico dalam melakukan pemasaran masih konservatif dengan pertemuan, negosiasi dan order secara temu fisikdan terbatas untuk bertransaksi di wilayah Yogyakarta saja. Jangkauan yang terbatas ini diharapkan dapat diperluas dengan sistem online yang diinginkan oleh Almico agar dapat menjangkau pelanggan dengan area yang lebih luas dengan menggunakan website. Namun demikian kesulitannya adalah belum ada perancangan yang cukup representative mewakili proses-proses di dalam perusahaan. Perancangan perlu memadukan setiap proses yang terjadi di perusahaan dengan menggunakan database yang sesuai.

Sistem pelayanan konsultasi saat ini masih konservatif menggunakan email, HP saja tanpa memanfaatkan fasilitas online berbasis web yang bisa lebih terorganisir, tertata dan tercatat databasenya. Sehingga data pelanggan dapat ditelusuri oleh perusahaan untuk di prospek kembali untuk repeat order, maupun untuk meminta referensi calon pelanggan baru. Data kontak yang diperoleh perusahaan sebagai calon pelanggan pun juga belum dapat terrecord dengan baik. Padahal jika data potensial pelanggan ini dapat di koneksikan dengan perusahaan, maka profil perusahaan dapat tersampaikan ke pelanggan via internet tanpa harus menggunakan cetak brosur.
Namun karena belum ada website, saat ini perusahaan banyak berkomunikasi dengan pelanggannya terbatas menggunakan cara konvensional dan mengkomunikasikan ke pelanggannnya satu per satu via namecard maupun brosur saja. Tentu saja cara ini dapat digunakan untuk menjalankan bisnis Almico, namun operasionalnya akan menjadi sangat terbatas di wilayah Yogyakarta. Dengan adanya website yang terkoneksi dengan social media akan membuat Almico Riset lebih dikenal di kalangan yang jauh lebih luas di luar Yogyakarta, sehingga pasarnya semakin luas.

Proses konsultasi akan dipermudah bila adanya website, karena pelanggan akan mendapat banyak informasi terlebih dahulu sesuai dengan adanya penjelasan layanan di website. Ini akan membuat pelanggan memahami kondisi potensi permasalahannya yang akan dibantu penyelesaiannya oleh Almico Riset. Dengan demikian waktu untuk memprospek pelanggan menjadi lebih singkat dan Almico memperoleh kemudahan dalam business introduction ke calon pelanggan.

Adanya website yang lebih representative dan bisa melakukan chat online dengan pelanggan maupun calon pelanggan, diharapkan akan dapat mendongkrakcorporate image perusahaan sehingga Almico Riset menjadi lebih percaya diri saat menghadapi klien dan dapat memiliki posisi tawar yang lebih baik dalam bernegosiasi.

Satu hal yang perlu diperhatikan adalah nama klien harus dijaga kerahasiaannya, agar tidak ter-published.Setelah klien atau pelanggan berkonsultasi dengan Almico Riset maka tahap selanjutnya adalah closing dengan pelanggan melakukan order terhadap project yang diminta. Tentu saja tidak setiap calon pelanggan melakukan order, beberapa mungkin hanya sekedar bertanya atau mengumpulkan informasi saja. 
Pesanan yang disepakati ditentukan nilainya di awal dan rincian order yang akan di selesaikan. Pelanggan-pelanggan yang melakukan transaksi ini belumlah terdatabase dengan rapi. Kesulitan akses dengan pelanggan yang datanya hilang sering membuat terputusnya komunikasi sehingga order tidak dapat berkelanjutan. Hal ini yang harus di antisipasi dengan data pelanggan yang lebih baik.Bila data pelanggan dan project dapat dibuat lebih baik, akan lebih mudah perusahaan melakukan marketing terstruktur dalam meningkatkan transaksi ordernya.

Harga yang dipakai sangat customized sesuai dengan jenis pekerjaan dan load project yang diberikan klien/pelanggan. Harga ini ditentukan atas penilaian berdasar konsultasi yang di lakukan di tahap sebelumnya. Harga di verifikasi oleh owner menggunakan dokumen manual. Namun demikian rencananya, paket standar untuk translate harga per lembar dan paket olah data per proses akan diberikan acuan harga standar nya.

Pengingkatan order ini harus melihat kembali kapasitas perusahaan dengan jumlah karyawannya dan kemampuan handling project. Karena bila project overload, perusahaan juga mengalami kesulitan dalam memberikan layanan terbaiknya.Proses selanjutnya setelah terjadi transaksi adalah proses pembayaran DP yang dilakukan oleh pelanggan dengan nilai DP ditentukan 30\% dari total nilai proyek sebagai tanda kesepakatan harga proyek. Pelunasan dilakukan saat serah terima hasil olah data atau terjemah yang sudah diberikan.Project yang diterima kemudian diberikan kepada staf yang spesialisasi di bidang tersebut untuk diolah. Lama pengerjaan tergantung dengan banyaknya order. Setelah selesai di proses kemudian hasil pekerjaan di kirim kembali kepada pelanggan melalui email.Di Almico, karyawan tidak diberikan remunerasi gaji tetap melainkan menggunakan sistem bagi hasil, dimana Perusahaan mendapat bagian $30 \%$ dan karyawan yang mengerjakan memperoleh $70 \%$ dari nilai net project (sudah dikurangi biaya) dan dibayarkan saat ada pelunasan dari pelanggan.

II. ANALISIS KEBUTUHAN

2.1. Performance

\begin{tabular}{|c|c|c|}
\hline $\begin{array}{c}\text { JENIS } \\
\text { ANALISI } \\
\mathbf{S}\end{array}$ & $\begin{array}{c}\text { KELEMAHA } \\
\text { N SISTEM } \\
\text { LAMA }\end{array}$ & $\begin{array}{l}\text { SISTEM YANG } \\
\text { DIAJUKAN }\end{array}$ \\
\hline $\begin{array}{l}\text { Performan } \\
\text { ce }\end{array}$ & $\begin{array}{l}\text { Sistem record } \\
\text { data transaksi } \\
\text { dengan } \\
\text { pelanggan dan } \\
\text { remunerasi } \\
\text { yang masih } \\
\text { manual lebih } \\
\text { riskan terhadap } \\
\text { terjadinya } \\
\text { kesalahan } \\
\text { dalam } \\
\text { pemrosesan } \\
\text { data yang } \\
\text { memerlukan } \\
\text { proses } 2 \text { hari } \\
\text { kerja }\end{array}$ & $\begin{array}{l}\text { Proses bisnis di } \\
\text { perusahaan diolah } \\
\text { menggunakan } \\
\text { sistem berbasis } \\
\text { komputer yaitu } \\
\text { dengan software } \\
\text { proses transaksi } \\
\text { dan penghitungan } \\
\text { remunerasi } \\
\text { berdasar order } \\
\text { pelanggan secara } \\
\text { otomatis. Proses } \\
\text { kalkulasi dan report } \\
\text { secara manual akan } \\
\text { hilang dan terganti } \\
\text { dengan menu } \\
\text { laporan yang bisa } \\
\text { diakses dengan } \\
\text { mudah }\end{array}$ \\
\hline $\begin{array}{l}\text { Informatio } \\
n\end{array}$ & $\begin{array}{l}\text { Dengan sistem } \\
\text { yang masih } \\
\text { manual } \\
\text { informasi yang } \\
\text { ingin } \\
\text { disampaikan } \\
\text { menjadi lebih } \\
\text { lama dan } \\
\text { terbatas, banyak } \\
\text { informasi yang } \\
\text { tidak } \\
\text { tersampaikan. } \\
\text { Customer } \\
\text { banyak yang } \\
\text { tidak } \\
\text { mengetahui } \\
\text { keberadaan } \\
\text { perusahaan ini. }\end{array}$ & $\begin{array}{l}\text { Dengan sistem baru } \\
\text { berbasis web maka } \\
\text { proses informasi } \\
\text { akan lebih cepat } \\
\text { diterima khalayak } \\
\text { umum dan semakin } \\
\text { banyak orang yang } \\
\text { mengetahui profil } \\
\text { perusahaan } \\
\text { Informasi menjadi } \\
\text { lebih mudah } \\
\text { diakses pelanggan } \\
\text { tanpa harus tatap } \\
\text { muka. }\end{array}$ \\
\hline Economic & $\begin{array}{l}\text { Biaya } \\
\text { komunikasi yang } \\
\text { dikeluarkan akan } \\
\text { lebih banyak } \\
\text { dalam personal } \\
\text { selling yang } \\
\text { harus dilakukan } \\
\text { kepada setiap } \\
\text { pelanggan dan }\end{array}$ & $\begin{array}{l}\text { Perlu biaya untuk } \\
\text { desain dan } \\
\text { pembuatan website } \\
\text { serta biaya untuk } \\
\text { maintenance } \\
\text { system online nya. } \\
\text { Ada peluang untuk } \\
\text { memperluas pasar } \\
\text { yang berarti }\end{array}$ \\
\hline
\end{tabular}




\begin{tabular}{|c|c|c|}
\hline $\begin{array}{c}\text { JENIS } \\
\text { ANALISI } \\
\mathbf{S}\end{array}$ & $\begin{array}{c}\text { KELEMAHA } \\
\text { N SISTEM } \\
\text { LAMA }\end{array}$ & $\begin{array}{l}\text { SISTEM YANG } \\
\text { DIAJUKAN }\end{array}$ \\
\hline & $\begin{array}{l}\text { calon pelanggan. } \\
\text { Waktu dalam } \\
\text { pendekatan } \\
\text { pelanggan juga } \\
\text { dilakukan } \\
\text { berulang-ulang } \\
\text { memberikan } \\
\text { penjelasan } \\
\text { sehingga } \\
\text { mengurangi nilai } \\
\text { produktivitas } \\
\text { dalam } \\
\text { mengerjakan } \\
\text { proyek. } \\
\text { Proses } \\
\text { mengenalkan } \\
\text { perusahaan } \\
\text { kepada calon } \\
\text { pelanggan } \\
\text { dilakukan } \\
\text { dengan } \\
\text { menyebar } \\
\text { brosur. Tentu } \\
\text { saja ini } \\
\text { membutuhkan } \\
\text { biaya cetak } \\
\text { brosur. }\end{array}$ & $\begin{array}{l}\text { meningkatkan } \\
\text { order sehingga } \\
\text { pendapatan } \\
\text { perusahaan dan } \\
\text { karyawan dapat } \\
\text { meningkat. } \\
\text { Meningkatnya } \\
\text { kualitas perusahaan } \\
\text { dengan berbasis IT } \\
\text { membuat corporate } \\
\text { image perusahaan } \\
\text { lebih baik, } \\
\text { sehingga dapat } \\
\text { memposisikan } \\
\text { kembali harga jual } \\
\text { di pasar dengan } \\
\text { harga yang lebih } \\
\text { baik dan } \\
\text { menguntungkan. } \\
\text { Perlu adanya } \\
\text { kalkulasi insentif } \\
\text { remunerasi bahwa } \\
\text { perusahaan } \\
\text { memperoleh } 70 \% \\
\text { dan karyawan } 30 \% \\
\text { dari total net } \\
\text { project } \\
\text { Biaya cetak brosur } \\
\text { dapat dipangkas } \\
\text { 50\%, hanya } \\
\text { diperlukan untuk } \\
\text { pelanggan yang } \\
\text { membutuhkan saat } \\
\text { dilakukan personal } \\
\text { selling saja }\end{array}$ \\
\hline Control & $\begin{array}{l}\text { Pengendalian } \\
\text { secara manual } \\
\text { memungkinkan } \\
\text { terjadinya } \\
\text { kehilangan data } \\
\text { dan } \\
\text { ketidakakuratan } \\
\text { dalam control } \\
\text { sehingga rentan } \\
\text { kesalahan }\end{array}$ & $\begin{array}{l}\text { Dengan sistem } \\
\text { berbasis web maka } \\
\text { control kinerja } \\
\text { karyawan dan } \\
\text { pembuatan laporan } \\
\text { akan lebih mudah } \\
\text { dilakukan dan } \\
\text { memperkecil } \\
\text { kemungkinan } \\
\text { terjadinya } \\
\text { kesalahan. } \\
\text { Database } \\
\text { pelanggan akan } \\
\text { lebih rapih dan } \\
\text { tersimpan dan } \\
\text { terupdate dengan } \\
\text { baik } \\
\text { Pembuatan laporan }\end{array}$ \\
\hline
\end{tabular}

\begin{tabular}{|c|c|c|}
\hline $\begin{array}{c}\text { JENIS } \\
\text { ANALISI } \\
\mathbf{S}\end{array}$ & $\begin{array}{c}\text { KELEMAHA } \\
\text { N SISTEM } \\
\text { LAMA }\end{array}$ & $\begin{array}{l}\text { SISTEM YANG } \\
\text { DIAJUKAN }\end{array}$ \\
\hline & & $\begin{array}{l}\text { transaksi juga akan } \\
\text { lebih bisa } \\
\text { dimonitor untuk } \\
\text { pencapaian target } \\
\text { pendapatan setiap } \\
\text { bulan nya }\end{array}$ \\
\hline Eficiency & $\begin{array}{l}\text { Sistem } \\
\text { pendataan } \\
\text { pelanggan yang } \\
\text { dilakukan } \\
\text { secara manual } \\
\text { kurang efisien } \\
\text { karena } \\
\text { melakukan } \\
\text { dokumentasi } \\
\text { secara manual } \\
\text { potensi data } \\
\text { hilang lebih } \\
\text { besar }\end{array}$ & $\begin{array}{l}\text { Sistem database } \\
\text { berbasis website } \\
\text { lebih efisien karena } \\
\text { tidak perlu } \\
\text { dokumentasi } \\
\text { manual dan laporan } \\
\text { akan terproses } \\
\text { secara otomatis. } \\
\text { Terdapat efisiensi } \\
\text { waktu dan biaya } \\
\text { komunikasi } \\
\text { marketing yang } \\
\text { cukup besar dengan } \\
\text { pengelolaan } \\
\text { website }\end{array}$ \\
\hline Service & $\begin{array}{l}\text { Pelayanan } \\
\text { kepada } \\
\text { customer } \\
\text { memakan } \\
\text { banyak waktu } \\
\text { karena harus } \\
\text { menunggu } \\
\text { waktu bertemu } \\
\text { untuk } \\
\text { melakukan } \\
\text { proses negosiasi } \\
\text { dan transaksi. } \\
\text { Semua harus } \\
\text { dilakukan } \\
\text { berdasar temu } \\
\text { muka tanpa ada } \\
\text { representasi } \\
\text { perusahaan } \\
\text { sebagai profile } \\
\text { untuk } \\
\text { menjelaskan } \\
\text { produk. }\end{array}$ & $\begin{array}{l}\text { Pelayanan kepada } \\
\text { customer akan } \\
\text { lebih cepat karena } \\
\text { komunikasi dan } \\
\text { proses transaksi } \\
\text { bisnis dapat } \\
\text { dilakukan secara } \\
\text { online } \\
\text { Terdapat } \\
\text { representasi } \\
\text { company profile } \\
\text { yang berisi produk- } \\
\text { produk dan } \\
\text { penjelasan sistem } \\
\text { order secara lebih } \\
\text { jelas yang didesain } \\
\text { secara khusus } \\
\text { untuk menciptakan } \\
\text { kesan perusahaan } \\
\text { yang memiliki } \\
\text { kredibilitas tinggi } \\
\text { Kerahasiaan klien } \\
\text { harus dapat terjaga } \\
\text { dengan baik }\end{array}$ \\
\hline
\end{tabular}

\section{PERUMUSAN MASALAH}

\subsection{Performance}

Tabel 3.1 Perumusan Masalah dan Kebutuhan Fungsional Berdasar Analisis Performance 


\begin{tabular}{|c|c|c|}
\hline No & $\begin{array}{c}\text { Daftar } \\
\text { Identifikasi } \\
\text { Masalah }\end{array}$ & Kebutuhan Fungsional \\
\hline 1 & $\begin{array}{l}\text { Belum ada } \\
\text { analisis dan } \\
\text { perancangan } \\
\text { website yang bisa } \\
\text { memberikan } \\
\text { panduan untuk } \\
\text { membuat website }\end{array}$ & $\begin{array}{l}\text { Perlu dibuat sebuah } \\
\text { perancangan website } \\
\text { dimana Admin dapat } \\
\text { melakukan transaksi } \\
\text { melalui website } \\
\text { Perlu ada perancangan } \\
\text { database yang mendukung } \\
\text { sistem website. }\end{array}$ \\
\hline 2 & $\begin{array}{l}\text { Selama ini hanya } \\
\text { menggunakan } \\
\text { komunikasi } \\
\text { dengan } \\
\text { representative } \\
\text { personal via } \\
\text { namecard dan } \\
\text { brosur }\end{array}$ & $\begin{array}{l}\text { Admin dapat memasukkan } \\
\text { layanan jasa yang } \\
\text { disediakan perusahaan } \\
\text { Admin dapat } \\
\text { menambahkan layanan } \\
\text { jasa yang disediakan } \\
\text { perusahaan } \\
\text { Admin dapat menghapus } \\
\text { layanan jasa yang } \\
\text { disediakan perusahaan }\end{array}$ \\
\hline
\end{tabular}

\subsection{Information}

Tabel Error! No text of specified style in document.-1Perumusan Masalah dan Kebutuhan Fungsional Berdasar Analisis Information

\begin{tabular}{|c|c|c|}
\hline No & $\begin{array}{c}\text { Daftar Identifikasi } \\
\text { Masalah }\end{array}$ & $\begin{array}{l}\text { Kebutuhan } \\
\text { Fungsional }\end{array}$ \\
\hline 1 & $\begin{array}{l}\text { Perusahaan masih } \\
\text { lokal di Yogyakarta. } \\
\text { Sistem bisnis masih } \\
\text { konservatif dengan } \\
\text { pertemuan, negosiasi } \\
\text { dan order secara temu } \\
\text { fisik }\end{array}$ & $\begin{array}{l}\text { - Admin dapat } \\
\text { melakukan entri } \\
\text { transaksi bisnis yang } \\
\text { bersifat online }\end{array}$ \\
\hline 3 & $\begin{array}{l}\text { Sistem pelayanan } \\
\text { masih berdasar email, } \\
\text { Hp secara konservatif }\end{array}$ & 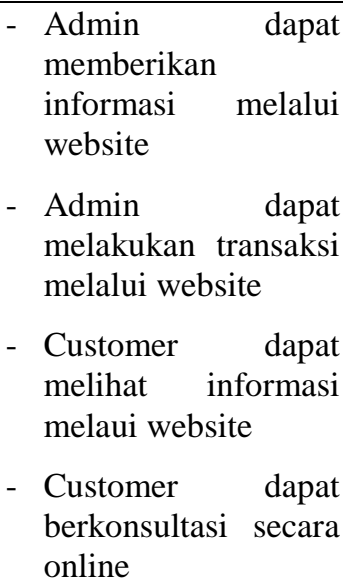 \\
\hline 4 & $\begin{array}{l}\text { Komunikasi } \\
\text { perusahaan dan } \\
\text { pelanggan terbatas, } \\
\text { interaksi hanya }\end{array}$ & $\begin{array}{l}\text { - Admin dapat } \\
\text { berkomunikasi } \\
\text { secara online dengan } \\
\text { customer }\end{array}$ \\
\hline
\end{tabular}

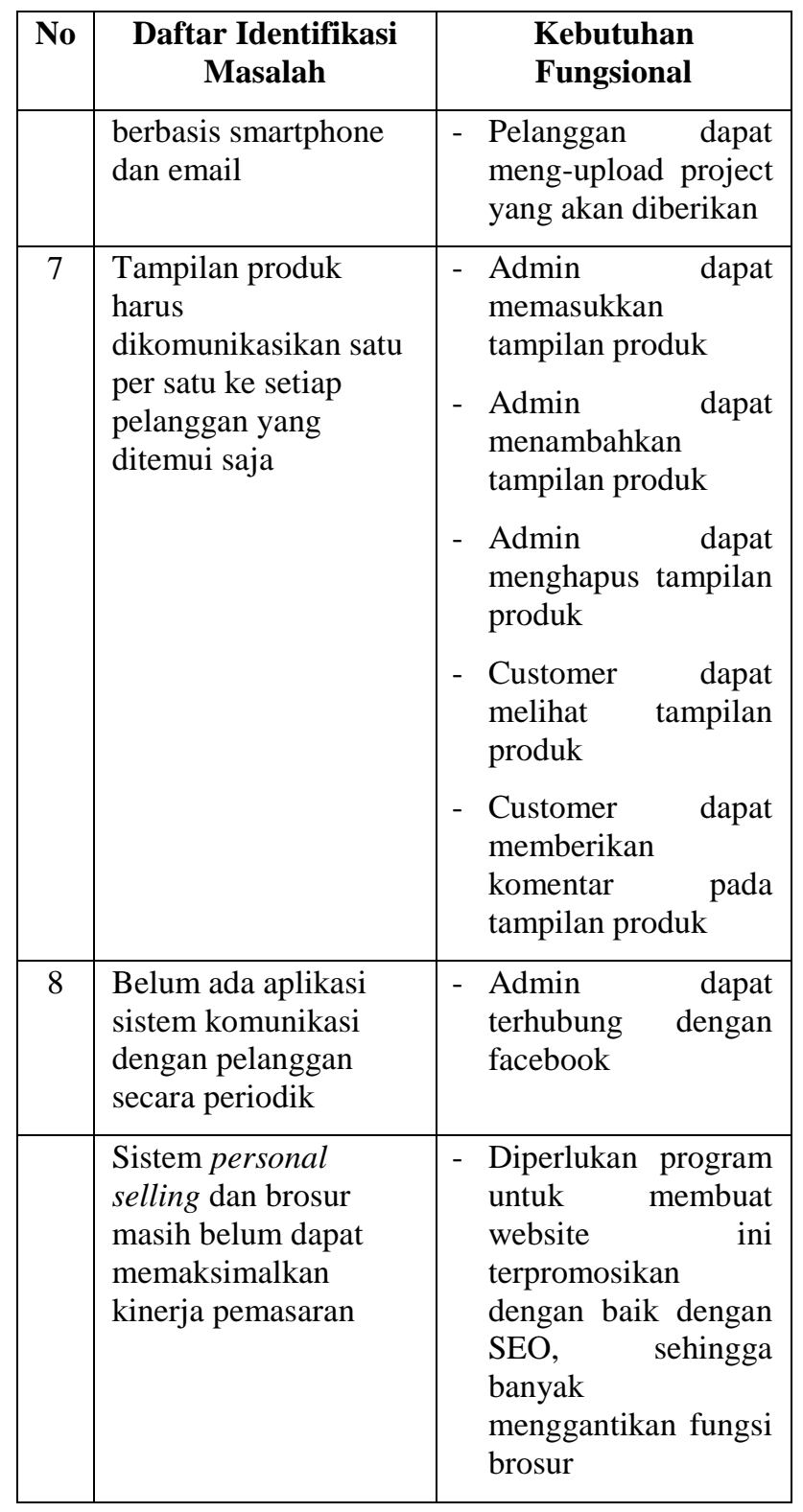

\subsection{Ekonomi}

Tabel Error! No text of specified style in document.-2 Perumusan Masalah dan Kebutuhan Fungsional Berdasar Economic

\begin{tabular}{|c|c|c|}
\hline No & $\begin{array}{c}\text { Daftar } \\
\text { Identifikasi } \\
\text { Masalah }\end{array}$ & Kebutuhan Fungsional \\
\hline 1 & $\begin{array}{l}\text { Paket standar } \\
\text { hanya } \\
\text { dikomunikasikan } \\
\text { ke pelanggan } \\
\text { yang dapat } \\
\text { ditemui secara } \\
\text { personal }\end{array}$ & 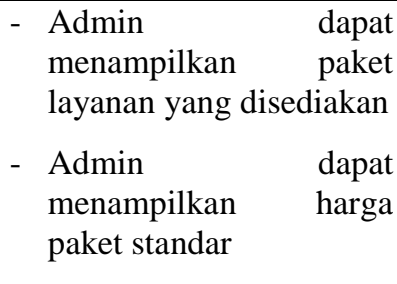 \\
\hline 2 & $\begin{array}{l}\text { Belum ada daftar } \\
\text { harga standar } \\
\text { yang dapat } \\
\text { dijadikan acuan, } \\
\text { karena transaksi } \\
\text { tidak terdata }\end{array}$ & 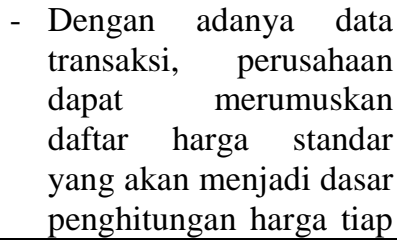 \\
\hline
\end{tabular}




\begin{tabular}{|c|c|c|}
\hline No & $\begin{array}{c}\text { Daftar } \\
\text { Identifikasi } \\
\text { Masalah }\end{array}$ & Kebutuhan Fungsional \\
\hline & dengan baik & $\begin{array}{l}\text { project. Tentu saja } \\
\text { karena harganya relative } \\
\text { negotiable, maka dapat } \\
\text { dilakukan penyesuaian } \\
\text { harga sesuai dengan } \\
\text { kesepakatan perusahaan } \\
\text { dengan pelanggan. } \\
\text { - Pelanggan maupun } \\
\text { calon pelanggan dapat } \\
\text { menengok situs website } \\
\text { untuk mengecek harga } \\
\text { yang ditawarkan untuk } \\
\text { produk jasa Almico }\end{array}$ \\
\hline 3 & $\begin{array}{l}\text { Penghitungan } \\
\text { remunerasi masih } \\
\text { manual }\end{array}$ & 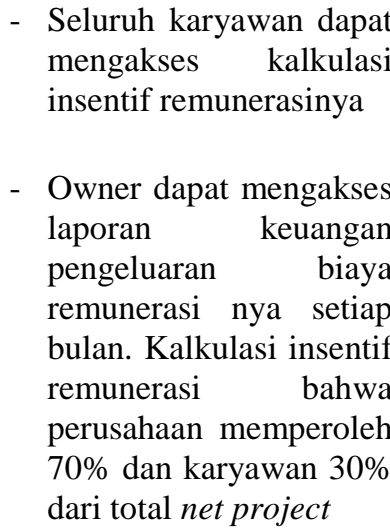 \\
\hline
\end{tabular}

\subsection{Kontrol}

Tabel Error! No text of specified style in document.-3Perumusan Masalah dan Kebutuhan Fungsional Berdasar Analisis Control

\begin{tabular}{|c|c|c|}
\hline No & $\begin{array}{c}\text { Daftar } \\
\text { Identifikasi } \\
\text { Masalah }\end{array}$ & Kebutuhan Fungsional \\
\hline 1 & $\begin{array}{l}\text { Database masih } \\
\text { bersifat manual. } \\
\text { Bahkan banyak } \\
\text { data pelanggan } \\
\text { yang tidak terdata } \\
\text { dengan baik da } \\
\text { nada risiko } \\
\text { kehilangan data }\end{array}$ & $\begin{array}{l}\text { - } \text { Admin dapat melakukan } \\
\text { input data pelanggan } \\
\text { - } \text { Admin dapat } \\
\text { menyimpan data } \\
\text { pelanggan } \\
\text { - } \text { Admin dapat mengedit } \\
\text { data pelanggan }\end{array}$ \\
\hline 2 & $\begin{array}{l}\text { Laporan } \\
\text { karyawan manual }\end{array}$ & $\begin{array}{lr}\text { - } \begin{array}{l}\text { Laporan } \\
\text { karyawan }\end{array} & \begin{array}{r}\text { kinerja } \\
\text { dan }\end{array} \\
\text { pencapaian } & \text { terhadap } \\
\text { target } & \text { perusahaan } \\
\text { menjadi lebih baik. } & \text { dapat } \\
\text { Owner } & \\
\text { memperoleh laporan } \\
\text { secara akurat dan } \\
\text { otomatis sehingga dapat } \\
\text { mengontrol kinerja } \\
\text { karyawan }\end{array}$ \\
\hline
\end{tabular}

\begin{tabular}{|c|c|c|}
\hline No & $\begin{array}{c}\text { Daftar } \\
\text { Identifikasi } \\
\text { Masalah }\end{array}$ & Kebutuhan Fungsional \\
\hline & & $\begin{array}{l}\text { Laporan transaksi dapat } \\
\text { di akses oleh owner }\end{array}$ \\
\hline
\end{tabular}

\subsection{Eficiency}

Tabel Error! No text of specified style in document.-4Perumusan Masalah dan Kebutuhan Fungsional Berdasar Analisis Eficiency

\begin{tabular}{|c|c|c|}
\hline No & $\begin{array}{c}\text { Daftar } \\
\text { Identifikasi } \\
\text { Masalah }\end{array}$ & $\begin{array}{l}\text { Kebutuhan } \\
\text { Fungsional }\end{array}$ \\
\hline & $\begin{array}{l}\text { Pendataan } \\
\text { pelanggan yang } \\
\text { masih manual } \\
\text { membuat follow } \\
\text { up dalam proses } \\
\text { personal selling } \\
\text { menjadi kurang } \\
\text { efektif dan } \\
\text { efisien. }\end{array}$ & $\begin{array}{l}\text {-Sistem database dapat } \\
\text { mendukung personal } \\
\text { selling. Staf dapat } \\
\text { mengakses data } \\
\text { pelanggan untuk } \\
\text { follow up prospect } \\
\text { yang dapat di update } \\
\text { di data } \\
\text { - }\end{array}$ \\
\hline
\end{tabular}

\subsection{Service}

Tabel Error! No text of specified style in document.-5Perumusan Masalah dan Kebutuhan Fungsional Berdasar Analisis Service

\begin{tabular}{|c|c|c|}
\hline No & $\begin{array}{c}\text { Daftar } \\
\text { Identifikasi } \\
\text { Masalah }\end{array}$ & Kebutuhan Fungsional \\
\hline 1 & $\begin{array}{l}\text { Pelanggan } \\
\text { harus } \\
\text { meluangkan } \\
\text { banyak waktu } \\
\text { untuk bertemu } \\
\text { konsultasi } \\
\text { tatap muka }\end{array}$ & $\begin{array}{l}\text { Pelanggan dapat } \\
\text { berinteraksi via website. }\end{array}$ \\
\hline 2 & $\begin{array}{l}\text { Daftar nama } \\
\text { klien yang } \\
\text { hilang, dapat } \\
\text { menjadi } \\
\text { sebuah risiko } \\
\text { bisnis }\end{array}$ & $\begin{array}{l}\text { Pelanggan akan mendapat } \\
\text { registrasi dan login } \\
\text { dengan tingkat keamanan } \\
\text { yang baik unntuk } \\
\text { menjaga kerahasiaan } \\
\text { klien }\end{array}$ \\
\hline & $\begin{array}{l}\text { Pelanggan } \\
\text { tidak dapat } \\
\text { mengikuti } \\
\text { updatenews } \\
\text { perusahaan } \\
\text { sehingga ada } \\
\text { kemungkinan } \\
\text { kehilangan } \\
\text { kontak. Tidak } \\
\text { ada fasilitas }\end{array}$ & $\begin{array}{lr}\text { Website/Admin } & \text { dapat } \\
\text { terkoneksi dengan social } \\
\text { media } \\
\text { Facebook.Keuntungannya } \\
\text { adalah pelanggan dapat } \\
\text { mengikuti } & \text { update news } \\
\text { Almico. } & \text { Dengan } \\
\text { demikian } & \text { pelanggan } \\
\text { yang.udah } & \text { pernah } \\
\text { orderakan } & \text { selalu terikat }\end{array}$ \\
\hline
\end{tabular}




\begin{tabular}{|c|l|l|}
\hline No & \multicolumn{1}{|c|}{$\begin{array}{c}\text { Daftar } \\
\text { Identifikasi } \\
\text { Masalah }\end{array}$} & Kebutuhan Fungsional \\
\hline $\begin{array}{l}\text { social media } \\
\text { meng }\end{array}$ & $\begin{array}{l}\text { dengan perusahaan } \\
\text { sehingga dapat kembali } \\
\text { berinteraksi untuk repeat } \\
\text { order }\end{array}$ \\
\hline 9 & $\begin{array}{l}\text { Belum pernah } \\
\text { me-release } \\
\text { testimony } \\
\text { pelanggan. }\end{array}$ & $\begin{array}{l}\text { Customer dapat } \\
\text { memberikan komentar } \\
\text { terhadapat perusahaan } \\
\text { Admin dapat melihat data } \\
\text { komentar } \\
\text { Admin dapat menghapus } \\
\text { data komentar }\end{array}$ \\
\hline
\end{tabular}

\section{ANALISIS KEBUTUHAN NON}

\section{FUNGSIONAL:}

\section{1) Operasional}

a. Pada Server, menggunakan system operasi Linux atau CentOS

b. Komputer dengan Prosesor minimum $244 \mathrm{Mhz}$

c. Memory Komputer minimal $512 \mathrm{MB}$, rekomendasi $1 \mathrm{~GB}$

d. Hardisk minimal 20GB, Rekomendasi $40 \mathrm{~GB}$

\section{2) Security}

Sistem aplikasi maupun databasenya dilengkapi password dan hanya bisa diakses oleh user yang berhak. Dalam hal ini akses dari admin, pemilik perusahaan dan karyawan dibedakan hak aksesnya sesuai dengan otoritasnya

3) Informasi

a. Digunakan untuk menginformasikan apabila password yang dimasukkan oleh pengguna salah.

b. Selama menggunakan aplikasi user akan mendapatkan informasi sesuai dengan fungsi aplikasi yang diakses

\section{4) Kinerja}

Kecepatan, kapasitas, dan reliabilitas sistem:

a. Akurasi waktu dalam akses website cukup mudah diakses via android maupun PC/laptop

b. Backup data base secara continue

c. Data base yang selalu up data

\section{PENGUJIAN}

Untuk Menguji apakah kebutuhan pengguna sudah terpenuhi maka dilakukan pengujian sistem. Proses pengujian sistem perlu dilakukan untuk menentukan keberadaan, kualitas dan kemurnian dari atribut-atribut sistem aplikasi yang akan dibangun. Dalam penelitian ini, pengujian sistem dibatasi hanya pada fungsional sistem yang dijelaskan dalam bentuk skenario proses. Pengguna diberikan sebuah daftar cek (checklist) untuk mengevaluasi kebutuhan pengguna yang sudah dianalisa dan siap dibuat desain sistemnya. Jika skenario proses tersebut sudah sesuai dengan kebutuhan pengguna, dapat dikatakan bahwa analisa kebutuhan pengguna yang dibuat sudah dapat dibuat desain sistemnya. Penelitian ini terdapat skenario pengujian prosesyang terdiri dari:

1. skenario proses register

2. skenario proses login

3. skenario proses pemesanan

4. skenario proses pembayaran

5. skenario proses konfirmasi

6. skenario proses validasi

\section{PENUTUP}

Framework PIECES membantu pengembang sistem menemukan kebutuhan pengguna (user requirement). Adapun langkah-langkah dalam penyusunan kebutuhan pengguna, terlebih dahulu menentukan kebutuhan sistem secara fungsional dan non fungsional. Framework PIECES memiliki fokus pada fungsional sistem yang akan dibangun. Oleh karena itu untuk menguji baik atau buruknya framework tersebut digunakan skenario pengujian proses.

\section{DAFTAR PUSTAKA}

Deitel Paul, dkk. 2012. Internet and World Widw World: How to Program. $5^{\text {th }}$ edition. Prentice Hall. USA

Kniberg, H.(2007). Scrum and XP Practice.USA: C4Media.

Netci, dkk. 2016.Analisis dan Desain sistem Penggajian SMK 1 Imogiri. ANSI Class Agus Mulyanto. MTI Amikom Yogyakarta

Pressman Roger S dan Lowe David. 2009. Web Engineering: A practitioner's Approach.McGraw Hill New York

Silverburg, A.(2012). Agile Analytics in Higher Education. USA: Phytorion Susanto, Azhar (2004). Sistem Informasi Manajemen konsep dan 
pengembangannya.

Bandung:Lingga Jaya 